\title{
Reproductive characteristics of the predator Podisus nigrispinus fed with an insect resistant soybean variety ${ }^{(1)}$
}

\author{
Fausto da Costa Matos Neto(2), José Cola Zanuncio(3), Marcelo Coutinho Picanço(3) and Ivan Cruz ${ }^{(4)}$
}

\begin{abstract}
The objective of this research was to evaluate the effect of the insect resistant soybean genotype IAC 17 on reproductive characteristics of Podisus nigrispinus (Dallas) (Heteroptera: Pentatomidae) females compared to the soybean insect susceptible genotype UFV 16. Treatments were: T1) females of $P$. nigrispinus fed on plants of the UFV 16 and Anticarsia gemmatalis Hübner (Lepidoptera: Noctuidae) caterpillars reared on leaves of this variety; T2) females of $P$. nigrispinus fed on plants of the IAC 17 and A. gemmatalis caterpillars reared on leaves of this variety. Longevity of females, pre-oviposition, oviposition and pos-oviposition periods, number of eggs and egg masses/ female, egg weight, interval between egg mass laying, number of eggs/egg mass, percentage of nymphs, number of nymphs/female and total number of prey killed/female of P. nigrispinus were evaluated. Most of the characteristics evaluated showed similar results between treatments, but the oviposition period was longer for females reared on the resistant genotype than on the susceptible one and the percentage of total females that laid eggs was lower on the IAC 17. Also, the resistant genotype caused higher mortality of P. nigrispinus females at the beginning of its adult stage and egg production by females of this predator was better spread along its adult stage with this resistant genotype. On the other hand, results suggest no effect of the resistant genotype on the offspring of this predator.
\end{abstract}

Index terms: Anticarsia gemmatalis, insects, reproduction, biological control, pest control.

\section{Características reprodutivas do predador Podisus nigrispinus alimentado com variedade de soja resistente a insetos}

\begin{abstract}
Resumo - O objetivo desta pesquisa foi avaliar o efeito do genótipo IAC 17, resistente a insetos, nas características reprodutivas de fêmeas de Podisus nigrispinus (Dallas) (Heteroptera: Pentatomidae), utilizando o genótipo susceptível UFV 16 como controle. Os tratamentos foram: T1) fêmeas de P. nigrispinus alimentadas com plantas de UFV 16 e lagartas de Anticarsia gemmatalis Hübner (Lepidoptera: Noctuidae), criadas em folhas desta cultivar; T2) fêmeas de P. nigrispinus alimentadas com plantas de IAC 17, e lagartas de A. gemmatalis, criadas em folhas desta cultivar. Avaliou-se a longevidade das fêmeas, períodos de pré-oviposição, oviposição e pós-oviposição, número de ovos e de posturas/fêmea, peso dos ovos, intervalo entre posturas, número de ovos/postura, porcentagem de ovos eclodidos, número de ninfas/fêmea e número total de presas mortas/fêmea de $P$. nigrispinus. A maioria das características avaliadas mostrou resultados semelhantes entre tratamentos, exceto o período de oviposição, que foi mais longo para fêmeas criadas no genótipo resistente que no susceptível, e a porcentagem de fêmeas que ovipositaram antes de morrer, que foi menor na IAC 17. Além disso, o genótipo IAC 17 causou maior mortalidade de fêmeas de P. nigrispinus no início de sua fase adulta e distribuição mais uniforme da produção de ovos ao longo do período adulto desse predador. Por outro lado, os resultados não sugerem efeito desse genótipo na prole do predador.
\end{abstract}

Termos para indexação: Anticarsia gemmatalis, insetos, reprodução, controle biológico, controle de pragas.

(1) Accepted for publication on September 12, 2001. Extracted from M. Sc. dissertation presented by the first author to Universidade Federal de Viçosa (UFV), Viçosa, MG, Brazil

(2) UFV, Dep. de Fitotecnia, CEP 36571-000 Viçosa, MG, Brazil. CNPq fellow. E-mail: fmatos@alunos.ufv.br
(3) UFV, Dep. de Biologia Animal. E-mail: zanuncio@mail.ufv.br, picanco@mail.ufv.br

(4) Embrapa-Centro Nacional de Pesquisa de Milho e Sorgo, Caixa Postal 151, CEP 35701-970 Sete Lagoas, MG, Brazil. E-mail: ivancruz@cnpms.embrapa.br 


\section{Introduction}

Soybean culture in Brazil demands a considerable amount of chemical products for pest control, which can cause environmental impacts besides affecting non-target organisms (Zanuncio et al., 1998). Due to the tendency of reducing use of chemical products, other methods of pest control have been studied, including host plant resistance and biological control. Thus, the Instituto Agronômico, Campinas, State of São Paulo, Brazil, developed the soybean genotype IAC 17 resistant to Anticarsia gemmatalis Hübner (Lepidoptera: Noctuidae) (Lourenção et al., 1997). Biological control organisms are important for maintenance of populations of insect pests below economic levels in soybean fields. Among these organisms, Podisus nigrispinus (Dallas) (Heteroptera: Pentatomidae) (Saavedra et al., 1997) is considered an important predator of Lepidoptera larvae associated to the soybean crop (Panizzi, 1990).

Since predatory bugs can also feed on plants (Stoner, 1970; Moreira et al., 1996/1997), this behavior can affect their development through the ingestion of deleterious substances from resistant plants (Price et al., 1980; Bozer et al., 1996; Traugott \& Stamp, 1997). As a consequence, adult longevity of this bug may be shorter and their fecundity and predation capacity could be lower on resistant plants. Kartohardjono \& Heinrichs (1984) observed higher population reduction of Nilaparvata lugens (Stal) (Homoptera: Delphacidae) by the predators Cyrtorhinus lividipennis Reuter (Hemiptera: Miridae) and Microvelia douglasi atrolineata (Bergroth) (Hemiptera: Veleiidae) on susceptible rice plants compared to resistant ones. Orr \& Boethel (1986) showed that the soybean genotype PI 227687, resistant to insects, delays egg production of the predator Podisus maculiventris (Say) (Heteroptera: Pentatomidae).

Studies about tri-trophic interaction levels can show that effects of resistant plants on natural enemies varies between species. The objective of this work was to evaluate the effects (direct or indirect) of the resistant soybean IAC 17 on reproductive characteristics of $P$. nigrispinus fed on caterpillars of A. gemmatalis reared with leaves of this genotype compared to others reared with leaves of the susceptible soybean genotype UFV 16.

\section{Material and Methods}

This study was developed in the Biological Control Laboratory of the Instituto de Biotecnologia Aplicada à Agropecuária (BIOAGRO), of the Universidade Federal de Viçosa (UFV), Brazil, at $25 \pm 2^{\circ} \mathrm{C}, 71 \pm 7 \% \mathrm{RH}$ and a photophase of 14 hours.

Each experimental unit consisted of a translucent recipient of soda (2-L), where one female of $P$. nigrispinus was placed. The bottom of these recipients was cut to allow fixing a cover of a plastic pot of $500 \mathrm{~mL}$ with a soybean plant, which was cultivated in a greenhouse. In the upper part of these recipients, a circular opening with $4 \mathrm{~cm}$ diameter was made and covered with tulle. Distilled water was supplied in anesthetic tubes (Assis Júnior et al., 1998). Soybean plants used were at the V 3 or V4 growth stage (Sediyama et al., 1989).

Anticarsia gemmatalis offered to P. nigrispinus were reared in the laboratory with soybean leaflets of the UFV 16 or the IAC 17 from plants at the V4 to R4 growth stage (Sediyama et al., 1989), cultivated in the field (Comissão de Fertilidade do Solo do Estado de Minas Gerais, 1989). These caterpillars were originated from parents reared with artificial diet.

Nymphs of $P$. nigrispinus, originated from eggs of females reared individually with larvae of Tenebrio molitor $\mathrm{L}$. (Coleoptera: Tenebrionidae) (Zanuncio et al., 1994), were individualized during II and III instars in Petri dishes $(15 \times 1.5 \mathrm{~cm})$, receiving one soybean leaflet from the UFV 16 (susceptible) or the IAC 17 (resistant), one $1.5 \mathrm{~cm}$ long A. gemmatalis larva (Saavedra et al., 1997), reared in the respective soybean variety, and distilled water inside anesthetic type tubes. At the fourth instar nymphs of this predator were transferred to 2-L recipients, containing one A. gemmatalis larva of similar size $(1.5 \mathrm{~cm})$, a soybean plant at V3 or V4 growth stage, changed every four days and distilled water. Nymphs of II or III instars of $P$. nigrispinus were maintained inside Petri dishes due to a high mortality rate observed for this insect in the 2-L recipients during these instars. Males of this predator were individualized in Petri dishes, receiving a leaflet from one of the soybean genotypes, the prey A.gemmatalis, with 3-4 $\mathrm{cm}$ long reared with leaflets of the UFV 16 or the IAC 17 soybean genotypes, according to the treatment, and distilled water.

Females of P. nigrispinus were coupled in the fourth day after their emergence with two to four day-old males (Zanuncio et al., 1996/1997; Mohaghegh et al., 1998), in 
the Petri dishes where the males were kept. After mating, each female constituting a replicate in a total of 15 and 14 females for the T1 and T2 treatments, respectively, was confined in the $2-\mathrm{L}$ recipients, with a 3 to $4 \mathrm{~cm}$ long caterpillar of $A$. gemmatalis reared with leaflets of the UFV 16 and one plant of this variety (T1); a caterpillar of A. gemmatalis, of similar size, reared with leaflets of the IAC 17 and one plant of this variety in the 2-L recipient (T2). Soybean plants were changed every four days and the leaflets each day; the prey was substituted whenever it was killed or when it showed no movements. After laying approximately 100 eggs (Torres et al., 1997), each female of $P$. nigrispinus was mated again, with the same male in the described conditions. Dead males were substituted by others of the same treatment.

The number of preyed caterpillars was counted even during the period of the sexual intercourse because females of predators such as Podisus sculptus Distant (Heteroptera: Pentatomidae) feed during this period (Nascimento et al., 1996).

Evaluations (twice a day) were made for survival and longevity of females, for pre and pos-oviposition periods, number of eggs and egg masses/female, egg weight, interval between egg laying, eggs/egg masses, egg viability, nymphs/ female and number of larvae killed per each $P$. nigrispinus female. These results were submitted to the non-parametric average test of Wilcoxon $(\mathrm{P}<0.05)$.

All replicates were considered, including females which did not lay eggs for evaluation of longevity, number of eggs and egg masses, nymphs/female and number of prey killed per female of $P$. nigrispinus. For the other characteristics, only data of females which laid eggs were considered.

\section{Results and Discussion}

Podisus nigrispinus females presented similar longevity, 36.20 and 27.21 days, on the soybean genotypes UFV 16 (susceptible) and IAC 17 (resistant), respectively (Table 1). This longevity was longer than that reported by Molina-Rugama et al. (1997) (23.0 days), when they used larvae of Musca domestica L. (Diptera: Muscidae) that is a lower quality prey than lepidopterous such as Bombyx mori L. (Lepidoptera: Bombycidae) for nymphs of $P$. nigrispinus (Zanuncio, T. et al., 1991). These authors also used vegetable material for feeding nymphs of this predator which could increase the longevity of females of predatory bugs (Ruberson et al., 1986). Zanuncio, J. et al. (1991) reported that female longevity of this predator was 28.1 days, when fed on B. mori caterpillars, a value similar to that obtained with $A$. gemmatalis reared with the resistant IAC 17 soybean variety. P. maculiventris also showed similar longevity with the susceptible soybean variety Davis and the resistant one PI 227687 (Orr \& Boethel, 1986).

In spite of similar longevity (Table 1), $P$. nigrispinus female showed higher mortality at the beginning of the adult stage when associated with the resistant variety (some females died between the third and the fourth day) (Figure 1). On the other hand mortality of $P$. nigrispinus females on the susceptible genotype occurred only after the $12^{\text {th }}$ day. The last female of $P$. nigrispinus associated with the resistant genotype IAC 17 died five days before the last one associated with the susceptible UFV 16 genotype (Figure 1).

P. nigrispinus females showed similar pre and post-oviposition periods with both genotypes (Table 1). This is similar to results of Orr \& Boethel (1986) who observed that the resistant soybean genotype PI 227687 did not affect the pre-oviposition period of $P$. maculiventris. Values found for the first period ( 6.60 and 7.63 days with the UFV 16 and the IAC 17 , respectively) are similar to the 8.5 days obtained by Torres et al. (1998).

The longest oviposition period of $P$. nigrispinus when associated with the resistant genotype (Table 1) demonstrates a deleterious effect of this variety on this predatory bug. This can reduce the number of generations of $P$. nigrispinus and, consequently, the predator population growth. However, this period for both genotypes was longer than that obtained by Zanuncio, T. et al. (1991), that is, 22.40 days.

The number of eggs/female was similar between treatments which showed that differences in the oviposition period did not affect the fecundity of P. nigrispinus (Table 1). The values obtained (554.00 and 357.79 eggs/female in the UFV 16 and the IAC 17, respectively) are higher than that observed by Torres et al. (1998), 325.00 eggs/female for this insect. Since these authors did not use plants, such differences could be explained by feeding this predator on plants as pointed out by Assis Júnior et al. (1998) and Moreira et al. (1996/1997). These authors obtained higher number of eggs/female for Supputius cincticeps Stal (Heteroptera: Pentatomidae) and 
higher net reproductive rate for Tynacantha marginata (Dallas) (Heteroptera: Pentatomidae) when they were supplied with eucalyptus seedlings and prey instead of only prey. Furthermore, Torres et al. (1998) developed their research with eggs from females of the rearing facility, while in the present study the eggs were collected from females reared individually from the second instar. This can justify, partly, higher values obtained and also the fact that these authors worked with different temperature

Table 1. Effect of the susceptible UFV 16 and the resistant IAC 17 soybean genotypes on reproductive characteristics (mean $\pm \mathrm{SEM}$ ) of females of Podisus nigrispinus (Heteroptera: Pentatomidae) fed with these plants and the prey Anticarsia gemmatalis (lepidotera: Noctuidae) reared with leaflets of these genotypes in laboratory. Temperature of $25 \pm 2^{\circ} \mathrm{C}$, RH of $71 \pm 7 \%$ and photophase of 14 hours. Number of replications: 15 for the UFV 16 and 14 for the $\operatorname{IAC} 17^{(1)}$.

\begin{tabular}{lcc}
\hline Characteristics & UFV 16 & IAC 17 \\
\hline Longevity (days) & $36.20 \pm 3.47 \mathrm{a}$ & $27.21 \pm 5.90 \mathrm{a}$ \\
Pre-oviposition period (days) & $6.60 \pm 0.54 \mathrm{a}$ & $7.63 \pm 1.13 \mathrm{a}$ \\
Oviposition period (days) & $26.80 \pm 3.11 \mathrm{~b}$ & $37.57 \pm 2.88 \mathrm{a}$ \\
Pos-oviposition period (days) & $2.80 \pm 0.61 \mathrm{a}$ & $2.50 \pm 1.10 \mathrm{a}$ \\
Eggs/female & $554.00 \pm 70.47 \mathrm{a}$ & $357.79 \pm 103.43 \mathrm{a}$ \\
Egg mass/female & $14.93 \pm 1.76 \mathrm{a}$ & $10.43 \pm 2.93 \mathrm{a}$ \\
Egg weight (mg) & $0.33 \pm 0.01 \mathrm{a}$ & $0.33 \pm 0.01 \mathrm{a}$ \\
Interval between egg laying (days) & $1.97 \pm 0.24 \mathrm{a}$ & $1.87 \pm 0.19 \mathrm{a}$ \\
Eggs/egg mass & $36.66 \pm 2.13 \mathrm{a}$ & $31.48 \pm 3.78 \mathrm{a}$ \\
Egg viability $(\%)$ & $71.59 \pm 9.83 \mathrm{a}$ & $85.40 \pm 3.66 \mathrm{a}$ \\
Nymphs/female & $447.07 \pm 84.64 \mathrm{a}$ & $319.93 \pm 93.58 \mathrm{a}$ \\
Prey killed/female & $12.47 \pm 1.43 \mathrm{a}$ & $8.43 \pm 2.29 \mathrm{a}$ \\
Females that laid eggs $(\%)^{(2)}$ & $100.00 \pm 0.00 \mathrm{~b}$ & $57.14 \pm 13.73 \mathrm{a}$ \\
\hline
\end{tabular}

(1)Means followed by the same letter in the line are not significantly different, according to the Wilcoxon test at $5 \%$ level. (2)Percentage of total females that laid eggs; six females fed with IAC 17 died before laying eggs.

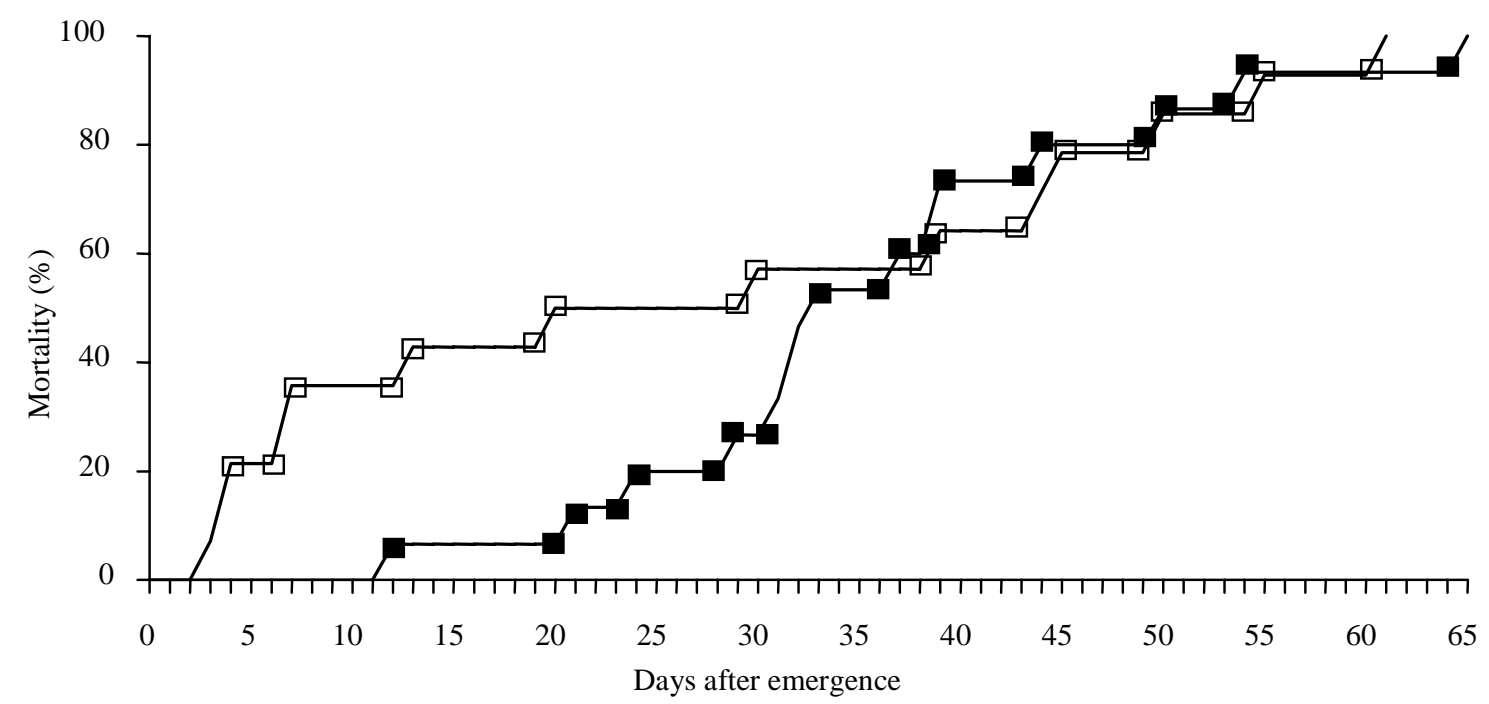

Figure 1. Mortality (\%) of females of Podisus nigrispinus (Heteroptera: Pentatomidae) associated with the soybean genotypes UFV 16 (susceptible, $\mathbf{\square}$ ) or the IAC 17 (resistant, $\square$ ) and the prey Anticarsia gemmatalis (lepidotera: Noctuidae) reared with leaflets of these genotypes. Temperature of $25 \pm 2^{\circ} \mathrm{C}$, RH of $71 \pm 7 \%$ and photophase of 14 hours. 
$\left(27^{\circ} \mathrm{C}\right)$. The delaying and the more uniform egg production associated with the resistant genotype (Figure 2), in spite of the similar number of eggs for both susceptible and resistant genotypes, were also reported by Orr \& Boethel (1986) for P. maculiventris. During the twenty-fifth initial days, females associated with the resistant IAC 17 , laid $39.05 \%$ of their total number of eggs, while in the case of the susceptible UFV 16 this value was $49.81 \%$. Higher egg production in this initial period, with the susceptible variety, can be due to a better survival rate of $P$. nigrispinus females (Figure 2). Up to the thirtyfifth day females of $P$. nigrispinus associated with the UFV 16 produced a higher number of eggs and
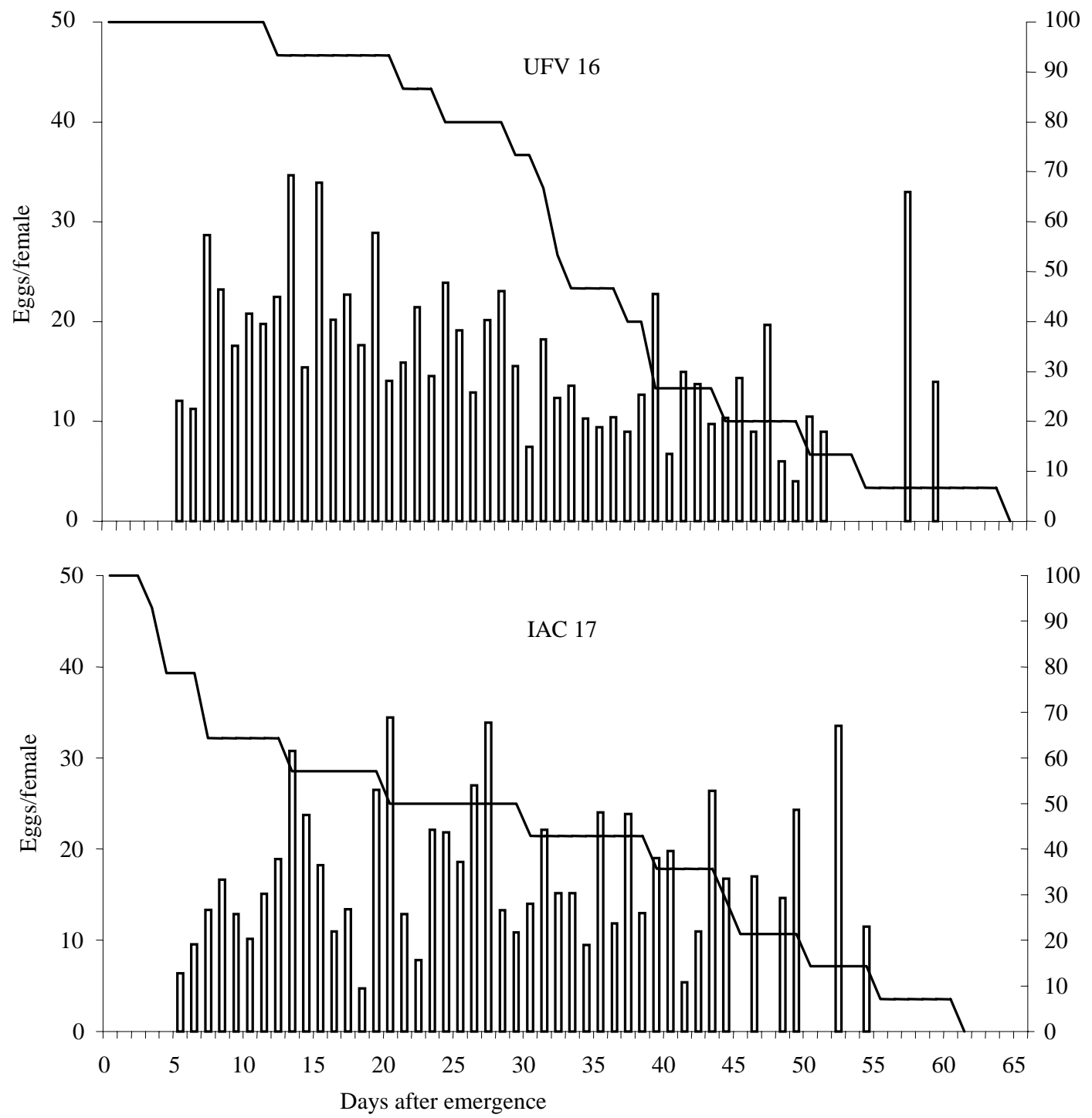

Figure 2. Total number of eggs per alive female ( $\square$ ) and survival ( - ) of females of Podisus nigrispinus (Heteroptera: Pentatomidae) associated with the soybean genotypes UFV 16 (susceptible) or the IAC 17 (resistant) and the prey Anticarsia gemmatalis (lepidotera: Noctuidae) reared with leaflets of these genotypes. Temperature of $25 \pm 2^{\circ} \mathrm{C}$, RH of $71 \pm 7 \%$ and photophase of 14 hours. 
higher survivorship than in the case of the resistant IAC 17. After this period this result showed an inversion between them but no differences found for this parameter at final life.

The number of egg masses/female was not significantly different between soybean genotypes (Table 1) but it was higher than the 7.8 egg masses obtained by Torres et al. (1997). Such difference could be explained, among other factors, by the supply of soybean plants to $P$. nigrispinus in this study. This was also observed by Moreira et al. (1996/1997) which showed that the addition of plant material to the diet of $T$. marginata increased its reproductive characteristics.

The period between egg mass deposition by $P$. nigrispinus females was not affected by the resistant soybean (Table 1), with similar value to the 2.43 days (Zanuncio, T. et al., 1991) and 2.40 days (Torres et al., 1998), but the number of eggs/egg mass in both soybean genotypes was lower than the 38.2 eggs/egg mass of Zanuncio, J. et al. (1991) and higher than the 21.50 eggs/egg mass of Torres et al. (1997).

Egg weight, egg viability, number of eggs/egg mass and number of nymphs/female of $P$. nigrispinus was similar with both soybean genotypes (Table 1), a fact that is important for integrated pest management of $A$. gemmatalis. However, since these results were obtained during only one generation, it is recommended to develop additional studies through several consecutive generations especially with the resistant genotype. Egg viability was similar to the value (81.0\%) reported by Zanuncio, T. et al. (1991), but the number of nymphs/female was higher than that obtained by Torres et al. (1998).

Due to the approach used, in which some characteristics considered all females (including those that did not lay eggs) and other characteristics considered only females that laid eggs, mathematical comparisons between reproductive characteristics of $P$. nigrispinus females, fed with the IAC 17, did not provide the results expected. For instance, the ratio of eggs/female by the number of egg masses/female should have resulted in 34.30 eggs/egg mass; however the value obtained was of 31.48 ; or the data 47.70 days, obtained for the sum of the pre-oviposition, oviposition and post-oviposition periods, was different from the 27.21 days obtained for female longevity of $P$. nigrispinus.
Similar number of prey killed with both soybean genotypes (Table 1) agrees with Orr \& Landis (1997), who did not verify differences in predation of egg and larvae of Ostrinia (Hiibner) (Lepidoptera: Pyralidae nubilalis feeding on the resistant or susceptible soybean genotypes.

The percentage of total females that laid eggs with the UFV 16 (100\%) was higher than with the IAC 17 $(57,14 \%)$ (Table 1$)$. It demonstrates a deleterious effect of the resistant variety on females of P. nigrispinus. Because some female laid no eggs with the IAC 17, the standard error of the mean for eggs/female was higher for this variety than for the UFV 16.

\section{Conclusions}

1. The resistant soybean IAC 17 causes a deleterious effect on $P$. nigrispinus increasing its oviposition period, the mortality rate of females at the beginning of their adult stage, and reducing the percentage of $P$. nigrispinus females that laid eggs.

2. The association of the resistant soybean IAC 17 and the predator P. nigrispinus can negatively affect some biological parameters of this natural enemy, but it is necessary to study this association under field conditions.

\section{Acknowledgements}

To the Conselho Nacional de Desenvolvimento Científico e Tecnológico (CNPq) and to the Fundação de Amparo à Pesquisa do Estado de Minas Gerais (Fapemig) for grants.

\section{References}

ASSIS JÚNIOR, S. B.; ZANUNCIO, T. V.; SANTOS, G. P.; ZANUNCIO, J. C. Efeito da suplementação de folhas de Eucalyptus urophylla no desenvolvimento e reprodução do predador Supputius cincticeps (Stal) (Heteroptera: Pentatomidae). Anais da Sociedade Entomológica do Brasil, Piracicaba, v. 27, n. 2, p. 245253, 1998 .

BOZER, S. F.; TRAUGOTT, M. S.; STAMP, N. E. Combined effects of allelochemical fed and scarce prey on the generalist insect predator Podisus maculiventris. Ecological Entomology, Oxford, v. 21, n. 4, p. 328-334, 1996. 
COMISSÃO DE FERTILIDADE DO SOLO DO ESTADO DE MINAS GERAIS (Lavras, MG). Recomendação para o uso de corretivos e fertilizantes em Minas Gerais: 4a aproximação. Lavras: Esal, 1989. $176 \mathrm{p}$.

KARTOHARDJONO, A.; HEINRICHS, E. A. Populations of the brown planthopper, Nilaparvata lugens (Stal) (Homoptera: Delphacidae), and its predator on rice varieties with different levels of resistance. Environmental Entomology, College Park, v. 13, n. 2, p. 359-365, 1984.

LOURENÇÃO, A. L.; MIRANDA, M. A. C.; PEREIRA, J. C. V. N. A.; AMBROSANO, G. M. B. Resistência de soja a insetos. X. Comportamento de cultivares e linhagens em relação a percevejos e desfolhadores. Anais da Sociedade Entomológica do Brasil, Piracicaba, v. 26, n. 3, p. 543-550, 1997.

MOHAGHEGH, J.; DE CLERCQ, P.; TIRRY, L. Effects of maternal age and egg weight on development time and body weight of offspring of Podisus maculiventris (Heteroptera: Pentatomidae). Annals of the Entomological Society of America, Lanham, v. 91, n. 3, p. 315-322, 1998.

MOLINA-RUGAMA, A. J.; ZANUNCIO, J. C.; TORRES, J. B.; ZANUNCIO, T. V. Longevidad y fecundidad de Podisus nigrispinus (Heteroptera: Pentatomidae) alimentado con Musca domestica (Diptera: Muscidae) y fríjol. Revista de Biología Tropical, San José, v. 45, n. 3, p. 1125-1130, 1997.

MOREIRA, L. A.; ZANUNCIO, J. C.; PICANÇO, M. C.; GUEDES, R. N. C. Effect of Eucalyptus feeding in the development, survival and reproduction of Tynacantha marginata (Heteroptera: Pentatomidae). Revista de Biología Tropical, San José, v. 44/45, n. 3/1, p. 253-257, 1996/1997.

NASCIMENTO, E. C.; ZANUNCIO, J. C.; MENIN, E.; FERREIRA, P. S. F. Aspectos biológicos, morfológicos e comportamentais de adultos de Podisus sculptus Distant (Heteroptera, Pentatomidae). Revista Brasileira de Zoologia, Curitiba, v. 13, n. 1, p. 151-157, 1996.

ORR, D. B.; BOETHEL, D. J. Influence of plant antibiosis through four trophic levels. Oecologia, Berlin, v. 70, n. 3, p. 242-249, 1986.

ORR, D. B.; LANDIS, D. A. Oviposition of European corn borer (Lepidoptera: Pyralidae) and impact of natural enemy populations in transgenic versus isogenic corn. Journal of Economic Entomology, Lanham, v. 90, n. 5, p. 905-909, 1997.
PANIZZI, A. R. Manejo integrado de pragas da soja no Brasil. In: CROCOMO. W. (Ed.). Manejo integrado de pragas. São Paulo: Ed. da Unesp, 1990. p. 293-321.

PRICE, P. W.; BOUTON, C. E.; GROSS, P.; McPHERON, B. A.; THOMPSON, J. N.; WEIS, A. E. Interactions among three trophic levels: influence of plants on interactions between insect herbivores and natural enemies. Annual Review of Ecology and Systematics, Palo Alto, v. 11, p. 41-65, 1980.

RUBERSON, J. R.; TAUBER, M. J.; TAUBER, C. A. Plant feeding by Podisus maculiventris (Heteroptera: Pentatomidae): effect on survival, development, and preoviposition period. Environmental Entomology, College Park, v. 15, n. 4, p. 894-897, 1986.

SAAVEDRA, J. L. D.; ZANUNCIO, J. C.; ZANUNCIO, T. V.; GUEDES, R. N. C. Prey capture ability of Podisus nigrispinus (Dallas) (Het., Pentatomidae) reared for successive generations on a meridic diet. Journal of Applied Entomology, Berlin, v. 121, n. 4, p. 327-330, 1997.

SEDIYAMA, T.; PEREIRA, M. G.; SEDIYAMA, C. S.; GOMES, J. L. L. Cultura da soja. Viçosa, MG: UFV, 1989. parte 2 .

STONER, A. Plant feeding by a predaceous insect, Geocoris punctipes. Journal of Economic Entomology, Baltimore, v. 63, n. 6, p. 1911-1915, 1970.

TORRES, J. B.; ZANUNCIO, J. C.; OLIVEIRA, H. N. Nymphal development and adult reproduction of the stinkbug predator Podisus nigrispinus (Het., Pentatomidae) under fluctuating temperatures. Journal of Applied Entomology, Berlin, v. 122, n. 4, p. 509-514, 1998.

TORRES, J. B.; ZANUNCIO, J. C.; OLIVEIRA, M. C. Mating frequency and its effect on female reproductive output in the stinkbug predator Podisus nigrispinus (Heteroptera: Pentatomidae). Mededelingen Faculteit Landbouwkundige \& Toegepaste Biologische Wetenschappen Universiteit Gent, Gent, v. 62, n. 2b, p. 491-498, 1997.

TRAUGOTT, M. S.; STAMP, N. E. Effects of chlorogenic acid and tomatine-fed caterpillars on performance of an insect predator. Oecologia, Berlin, v. 109, n. 2, p. $265-$ 272, 1997.

ZANUNCIO, J. C.; ALVES, J. B.; ZANUNCIO, T. V.; GARCIA, J. F. Hemipterous predators of eucalypt defoliator caterpillars. Forest Ecology and Management, Amsterdam, v. 65, n. 1, p. 65-73, 1994. 
ZANUNCIO, J. C.; BATALHA, V. C.; GUEDES, R. N. C.; PICANÇO, M. C. Insecticide selectivity to Supputius cincticeps (Stal) (Het.: Pentatomidae) and its prey Spodoptera frugiperda (J.E. Smith) (Lep.: Noctuidae). Journal of Applied Entomology, Berlin, v. 122, n. 3, p. 457-460, 1998.

ZANUNCIO, J. C.; NASCIMENTO, E. C.; SANTOS, G. P.; SARTÓRIO, R. C.; ARAÚJO, F. S. Aspectos biológicos do percevejo predador Podisus connexivus (Hemiptera: Pentatomidae). Anais da Sociedade Entomológica do Brasil, Piracicaba, v. 20, n. 2, p. 243249, 1991.
ZANUNCIO, J. C.; SAAVEDRA, J. L. D.; ZANUNCIO, T. V.; SANTOS, G. P. Incremento en el peso de ninfas y adultos de Podisus nigrispinus (Heteroptera: Pentatomidae) alimentados con dos tipos de larvas. Revista de Biología Tropical, San José, v. 44/45, n. 3/1, p. 241-245, 1996/1997.

ZANUNCIO, T. V.; BATALHA, V. C.; ZANUNCIO, J. C.; SANTOS, G. P. Parâmetros biológicos de Podisus connexivus (Hemiptera: Pentatomidae) em alimentação alternada com lagartas de Bombyx mori e larvas de Musca domestica. Revista Árvore, Viçosa, MG, v. 15, n. 3 , p. 308-315, 1991. 